\title{
PENGARUH MEDIA BONEKA WAYANG KARDUS TERHADAP KEMAMPUAN BERCERITA ANAK
}

\author{
Anisa'ul Fauziyah a, Aisyah ${ }^{\text {b }}$ \\ ${ }^{a, b}$ Program Studi Pendidikan Guru Pendidikan Anak Usia Dini, Fakultas Keguruan dan \\ Ilmu Pendidikan, Universitas PGRI Adi Buana Surabaya \\ e-mail: anisaulfauziyah.af@gmail.com
}

\begin{abstract}
This research is motivated by the story-telling ability for language development are designed to develop the potential of communication and vocabulary expansion. Through stories, children receive proper example of how to speak, asked for help, thank you, and defend themselves. Based on this, the media "Wayang Kardus" used as an alternative in learning. This study aims to determine the effect of the Media Wayang Kardus on Storytelling Ability of Student's Group B TK Sartiasari Wonorejo Surabaya. Indirectly storytelling can improve their language skills. This study is a One-Group Pretest-posttes Design. Results showed before and after exercise there is increased development of language skills of children in group B TK Sartiasari Surabaya. The results show the data $t=(23.117)$ is greater than $t$ table $=(2.042)$ with a significance level of $5 \%$. which means there is significant influence between Media Wayang Kardus on Storytelling Ability of children Group B TK Sartiasari Wonorejo Surabaya. Media Wayang Kardus Influential on Storytelling Ability of Children Group B TK Sartiasari Wonorejo Surabaya.
\end{abstract}

Keywords: Media Wayang Kardus (Stuffed Puppet Cartons), Storytelling Ability

\section{PENDAHULUAN}

Fadillah (2012: 18) menyebutkan bahwa anak usia dini ialah kelompok anak yang berada dalam proses pertumbuhan dan perkembangan yang bersifat unik. Yaitu, pola pertumbuhan dan perkembangan (koordinasi motorik halus dan kasar), intelegensi (daya pikir, daya cipta, kecerdasan emosi, dan kecerdasan spiritual, sosial emosional (sikap dan perilaku serta agama), bahasa, dan komunikasi yang khusus sesuai dengan tingkat pertumbuhan dan perkembangan anak.

Menurut Suyadi (2010: 12) Pendidikan anak usia dini merupakan serangkaian upaya sistematis dan terprogram dalam melakukan pembinaan yang ditujukan kepada anak sejak lahir sampai dengan usia 6 tahun yang dilakukan melalui pemberian rangsangan pendidikan untuk membantu pertumbuhan dan perkembangan jasmani serta rohani agar anak memiliki kesipan untuk memasuki pendidikan lebih lanjut.

Anak usia dini pada zaman sekarang, Mereka jauh lebih senang melakukan bermain dengan gadget dari pada berkomunikasi dengan lingkungan di sekitar. Dalam berkomunikasi, bahasa merupakan alat yang penting bagi setiap orang. Melalui berbahasa seseorang atau anak akan dapat mengembangkan kemampuan bergaul (social skill) dengan orang lain. Tanpa bahasa seseorang tidak akan dapat berkomunikasi dengan orang lain. Anak dapat mengekspresikan pikirannya menggunakan bahasa sehingga orang lain dapat menangkap apa yang dipikirkan oleh anak.

Kemampuan bercerita pada anak penting untuk dikembangkan karena tanpa disadari cerita tersebut 
mempengaruhi perkembangan pribadinya, membentuk sikap-sikap moral dan keteladanan.

Cerita adalah salah satu cara untuk menarik perhatian anak. Biasanya cerita yang disukai anak, yaitu cerita yang berkaitan dengan dunia binatang, seperti cerita si kancil ataupun yang sejenisnya, Fadilah dan Lilif (2013: 179).

Tingkat pencapaian perkembangan kemampuan bercerita yang harus dikembangkan pada anak usia dini yang disesuaikan dengan Permendiknas No 137 (2013), di antaranya:

1) Mengulang kalimat yang lebih kompleks. 2) Berkomunikasi secara lisan, memiliki perbendaharaan kata, serta mengenal simbol-simbol untuk persiapan membaca, menulis dan berhitung 3)Menyusun kalimat sederhana dalam struktur lengkap (pokok kalimat-predikat-keterangan). 4) Memiliki lebih banyak kata-kata untuk mengekpresikan ide pada orang lain. 5) Melanjutkan sebagian cerita/dongeng yang telah diperdengarkan

Dilihat dari standart pencapaian perkembangan anak di atas, sebagian besar dari anak didik kelompok B di Taman Kanak-kanak Sartiasari Wonorejo Surabaya tahun ajaran 2016-2017 masih belum memiliki kamampuan yang diharapkan dalam standart pencapaian perkembangan kemampuan bercerita anak usia 4-6 tahun.

Berdasarkan observasi awal serta wawancara dengan pendidik dan orang tua anak didik, penulis menemukan kemampuan berceita pada Taman Kanak-kanak (TK) Sartiasari Wonorejo Surabaya kelompok B yang berjumlah 31 anak didik tahun ajaran 2016-2017 sebagian besar masih belum menemukan yang lebih sesuai.
Metode dalam proses pembelajaran yang digunakan pendidik kurang kompatibel dengan anak didik yang masih awal masuk jenjang Taman Kanak-kanak, pada akhirnya sering mengakibatkan keterhambatan perkembangan psikomotorik anak didik selanjutnya.

Permasalahan di atas jika tidak direspon oleh pendidik, kemungkinan besar akan memberi dampak yang kurang baik terhadap tahapan perkembangan psikomotorik anak didik berikutnya. Oleh karena itu stimulasi harus diberikan pada anak sesuai dengan tahapan serta dengan cara yang menyenangkan pula, karena motorik halus pada anak adalah salah satu titik fundamental untuk anak menyiapkan perkembangan selanjutnya.

Bercerita merupakan suatu proses kreatif anakanak. Cerita menawarkan kesempatan menginterprestasi dengan mengenali kehidupan di luar pengalaman langsung mereka. Manfaat bercerita sangat banyak terutama dalam pengembangan bahasa anak. Untuk membangkitkan rasa ingin tahu anak, bercerita dapat menggunakan alat bantu semisal media wayang. Dalam kaitan penelitian ini peneliti menggunakan wayang kardus.

Boneka wayang adalah permainan dengan boneka yang berbetuk wayang sederhana dengan meniru tokoh atau profil tertentu yang dapat dimainkan anak dalam kegiatan bermain peran dan mendongeng. Tujuan permainan boneka wayang adalah memberikan pengetahuan dan sikap budi pekerti melalui cerita-cerita fiksi atau legenda kepada anak. Permainan ini juga bertujuan untuk mengasah kreativitas, bahasa, emosi, bersosialisasi, keterampilan motorik halus khususnya pada jari-jari dan tangan. Sehingga dengan menggunakan media boneka wayang ini dapat memungkinkan agar anak 
tertarik untuk mengikuti proses pembelajaran dan agar pembelajaran lebih kreatif serta menyenangkan.

Nur Mustakim (2005:12) mengemukakan bahwa "Cerita adalah gambaran tentang kejadian suatu tempat, kehidupan binatang sebagai perlambang kehidupan manusia, kehidupan manusia dalam masyarakat, dan cerita tentang mite yang hidup dalam masyarakat kapan dan dimana cerita itu terjadi".

Supriyadi (2006: 4) berpendapat "Cerita anak adalah karya imajinatif dalam bentuk bahasa yang berisi pengalaman, perasaan, dan pikiran anak secara jujur, yang secara khusus ditujukan bagi anak-anak, ditulis oleh pengarang anak-anak atau orang dewasa".

Kata media merupakan bentuk jamak dari kata medium. Medium dapat didefinisikan sebagai perantara atau pengantar terjadinya komunikasi dari pengirim menuju penerima. Arief Sadiman, dkk. (2012: 6) mengatakan "Media adalah segala sesuatu yang dapat digunakan untuk menyalurkan pesan dari pengirim ke penerima sehingga dapat merangsang pikiran, perasaan, perhatian, dan minat serta perhatian siswa sehingga proses belajar dapat berjalan".

Irawati (tidak dicantumkan: 23) mengatakan bahwa "Di Inggris berkembang wayang boneka yang digerakkan dengan tangan. Karakter yang terkenal di Inggris kala itu adalah Judy Pounch. Karakter ini muncul pertama kali tahun 1662”.

Wayang kadang diartikan sebagai tiruan orang, benda bernyawa, dan benda lainnya yang terduat dari pahatan kulit binatang, kayu, kertas, dan rumput yang digunakan untuk memerankan tokoh dalam pertunjukan drama tradisional yang diperankan oleh dalang

\section{METODE PENELITIAN}

Penelitian ini menggunakan pendekatan kuantitatif dengan desain penelitian One Group Pretest-posttest Desaign.

Penelitian ini merupakan penelitian pre eksperimen design karena eksperimen jenis ini masih terdapat variabel luar yang ikut berpengaruh terhadap terbentuknya variabel terikat (Sugiyono, 2013:109). Penelitian ini dilaksanakan pada semester satu tahun ajaran 2016-2017. Tempat penelitian ini di TK Sartiasari Wonorejo Kota Surabaya dengan pengambilan data pada bulan November 2016. Sampel pada penelitian ini adalah anak kelompok B terdiri atas 31 anak didik. Sampel yang terpilih berdasarkan atas rendahnya kemampuan bercerita anak yang dimiliki dalam satu kelas.

\section{HASIL PENELITIAN}

Berikut ini peneliti akan mendeskripsikan data serta pembahasan mengenai "Pengaruh Media Boneka Wayang Kardus Terhadap Kemampuan Bercerita Anak Kelompok B TK Sartiasaru Wonorejo Surabaya". Pengumpulan data dan penyajian yaitu Pre-Test dan Post-Test dipaparkan dalam bentuk tabel yang selanjutnya dilakukan uji hipotesis. Pre-Test dan Post-Test diberikan terhadap 31 anak kelompok B TK Sartiasari Wonorejo Surabaya. 
Tabel Hasil Uji Hipotesis tentang Pengaruh Media Boneka

\begin{tabular}{llllll}
\multicolumn{5}{c}{ Wayang Kardus terhadap Kemampuan Bercerita Anak } \\
\hline Hipotesis & Sig. & Thit & Ttabel & $\mathrm{H}_{0}$ & $\mathrm{H}_{1}$ \\
& & & & & \\
Terdapat & $5 \%$ & 23,117 & 2,042 & Ditolak Diterima \\
pengaruh & $\mathrm{Db}=$ & & & & \\
penggunaan & $\mathrm{N}-1$ & & & \\
media boneka & $=31-1$ & & & \\
wayang & $=30$ & & & \\
kardus & & & & \\
tehadap & & & & \\
kemampuan & & & & \\
bercerita anak & & & & \\
kelompok B & & & & \\
TK Sartiasari & & & & \\
Wonorejo & & & \\
Surabaya. & & & \\
\hline
\end{tabular}

\section{Keterangan:}

Jumlah Responden $(\mathrm{N}) \quad=31$

$\mathrm{Db} \quad=\mathrm{N}-1=30$

thitung $\quad=23,117$

tabel $\quad=2,042$

Taraf signifikansi $95 \% \quad=23,117>2,042$

\section{PEMBAHASAN}

Berdasarkan tabel di atas maka hipotesis nol ditolak dan hipotesis kerja diterima. Hipotesis yang menyatakan ada pengaruh media boneka wayang kardus terhadap kemampuan bercerita anak kelompok B TK Sartiasari Surabaya diterima.

Dari data yang terkumpul dan dari hasil perhitungan analisis data dapat diketahui bahwa perkembangan kemampuan bercerita setelah dilakukan pembelajaran menggunakan media boneka wayang kardus meningkat sebesar 391poin. Sedangkan skor sebelum diberi perlakuan metode bercerita sebesar 267 poin dan berdasarkan hasil pengujian uji t diperoleh nilai 23,117 dengan tingkat signifikasi $0,05\left(\mathrm{t}_{\text {hitung }} \mathrm{t}_{0,05(31-1)}\right)$ yang berarti ada pengaruh media boneka wayang kardus terhadap kemampuan bercerita anak kelompok B TK Sartiasari Wonorejo Surabaya.

Cerita untuk perkembangan bahasa dirancang untuk mengembangkan potensi berkomunikasi dan perluasan kosa kata. Melalui cerita, anak memperoleh contoh bagaimana semestinya berbicara, meminta tolong, berterima kasih, dan membela diri.

Sebelum melakukan treatment media boneka wayang kardus peneliti mengobservasi tingkat perkembangan kemampuan bercerita anak TK kelompok B dan ada peningkatan yang signifikan pada perkembangan kemampuan bercerita setelah diberi perlakuan dengan media boneka wayang kardus. Upaya guru dalam menggunakan media yang tepat dan kreatif menunjang tercapainya perkembangan kemampuan bercerita anak dalam proses belajar mengajar dan pembelajaran menjadi lebih hidup serta menjadi lebih bermakna.

Suatu kesimpulan bahwa masalah yang diajukan yaitu apakah ada pengaruh media boneka wayang kardus terhadap kemampuan bercerita anak kelompok B TK Sartiasari Wonorejo Surabaya telah terjawab.

\section{SIMPULAN DAN SARAN}

\subsection{Simpulan}

Berdasarkan rumusan masalah dan tujuan penelitian yang telah ditetapkan, diperkuat dengan analisis data, dapat dibuktikan bahwa setelah diberikan pembelajaran menggunakan media boneka wayang kardus pada anak TK B terdapat perbedaan yang signifikan antara hasil (Pre-Test dan Post-Test) yaitu dari hasil nilai pre test yang sangat rendah setelah di lakukan perlakuan nilai post test sangat meningkat dengan baik.

Dengan demikian dapat disimpulkan bahwa Ada pengaruh media boneka wayang kardus terhadap kemampuan bercerita anak kelompok B TK Sartiasari Wonorejo Surabaya, sehingga hipotesis awal dalam penelitian ini dapat diterima. 


\subsection{Saran}

Berdasarkan hasil penelitian ini dapat drekomendasikan bahwa untuk mencapai hasil yang diharapkan dalam pengembangan bahasa peserta didik, dan agar dapat memberikan pengetahuan atau informasi baru bagi anak setelah anak mendengarkan cerita, maka seyogianya dalam membawakan cerita harus sesuai dengan tahap perkembangan anak, baik dari bahasa, media dan langkah-langkah pelaksanaannya, agar lebih efektif, komunikatif, dan menyenangkan bagi anak.

\section{PERNYATAAN TERIMA KASIH (jika}

\section{diperlukan)}

Pada kesempatan ini peneliti menyampaikan terima kasih dan penghargaan kepada Ibu Kepala TK Sartiasari beserta jajaran pendidiknya atas segala kesempatan, bantuan dan fasilitas yang diberikan kepada peneliti sehingga peneliti berhasil melaksanakan penelitian ini sampai tuntas.

\section{REFERENSI}

Arikunto, Suharsimi. (2006) Prosedur Penelitian Suatu Pendekatan Praktek. Jakarta: Rineka Arsyad, Azhar.(2009) Media Pembelajaran. Jakarta: PT Raja Grafindo Persada

Fadillah, Muhammad.(2012) Desain Pembelajaran PAUD. Jogjakarta: Ar-Ruzz Media

Fadillah Muhamad dan Khorida Mualifatu Lilif. (2013) Pendidikan Karakter Anak Usia Dini. Yogyakarta: Ar-Ruzz Media

Irawati. Asal Usul Boneka. Penerbit: Iravi Jaya.

Peraturan Menteri Pendidikan Republik Indonesia No. 137 Tahun 2013 Tentang Standart Pendidikan Anak Usia Dini. Jakarta

Sadiman, Arief. (2012) Media Pendidikan. Penerbit: rajagrafindo Persada

Sugiyono. (2011) Metode penelitian kuantitatif, kualitatif, dan R\&D. Bandung: Alfabeta.

Sugiyono. (2013) Metode Penelitian Pendidikan. Bandung: Alfabeta 